\title{
A Demographic Study of an Eskimo Village on the North Slope of Alaska
}

\author{
FREDERICK A. MILAN ${ }^{1}$
}

\begin{abstract}
The Eskimo population of Wainwright was found to have the following demographic characteristics in 1968: A total number of 308 (169 males; 139 females) with a median age of 16.1 years. Sixty-seven were hybrids. Fecundity was high (7.9 conceptions for all women; 10.5 live births for 17 post-menopausal women). The rate of twin births $(27$ per 1,000$)$ was twice that of a Caucasian population. The sex ratio at birth was skewed $(108.2 / 100)$. Infant mortality was high, for only 81 per cent of all live births survived to age 5 as compared to 97.3 per cent for the U.S.A. in 1959. Marked differential survival of children was observed since one-fifth of the women were responsible for 47 per cent of the living offspring. Mortality rates have declined. Recent introduction of birth control will make birth rate, not survival, the determinant of genetic content of the succeeding generations.
\end{abstract}

RÉSUMÉ. Étude démographique d'un village esquimau du versant nord de l'Alaska. En 1968, la population esquimaude de Wainwright présentait les caractéristiques démographiques suivantes: un nombre total de 308 individus (169 hommes, 139 femmes) dont l'âge médian était de 16.1 ans. Soixante-sept étaient métis. La fécondité était élevée: 7.9 conceptions pour toutes les femmes: 10.5 naissances vivantes pour 17 femmes post-ménopause. Le taux de naissances jumelles (27 pour mille) était de deux fois celui d'une population caucasienne. Le rapport des sexes à la naissance était biaisé $(108.2 / 100)$. La mortalité infantile était élevée, car seulement 81 pour cent des enfants nés vivants survivaient jusqu'à l'âge de 5 ans, en comparaison avec un pourcentage de 97.3 aux E.-U. en 1959. On observait une survivance inégale marquée des enfants, car un cinquième des enfants était responsable de 47 pour cent des rejetons vivants. Les taux de mortalité ont décliné. L'introduction récente du contrôle des naissances fera qu'à l'avenir le taux de natalité, et non plus la survivance, sera déterminant du bagage génétique des prochaines générations.

РЕЗЮМЕ. Демографические исследованил поселка эскимосов в северной части Aляски. Иеследования показали, что по состоянию на 1968 год население әскимосов в поселке Уайнрайт имело следующие демографические показатели: общее число жителей - 308 (169 мужжчин и 139 женщин); средний возраст 16,1 лет; метисов - 67 человек. Плодовитость была высокой $(7,9$ зачатий на обпее число женщин; 10,5 живых родов на 17 женцин, пропедших климактерический период). Частота рождения двойни (27 елучаев на каждые 1000 родов) была в два раза выше, чем для европеидной расы. Отнопение полов при рождении - асимметричное $(108,2 / 100)$. Детская смертность была значительной, т.к. только $81 \%$ родившихся детей доживало до пятилетнего возраста, в то время как в СIIA по данным на 1959 год эта же цифра составляла 97,3\%. Наблюдалась ярко выраженная разница в степени выживаемости детей: $47 \%$ всех выживших детей принадлежало лишь $1 / 5$ общего числа женщин. В последнее время детская смертность уменышается. Начавшееся недавно применение противозачаточных средств приведет $k$ тому, что не смертность, а деторожддаемость станет определяющим фактором генетического содержания последующих поколений.

1 Department of Anthropology, The University of Wisconsin, Madison, U.S.A. 


\section{INTRODUCTION}

This paper describes the demography of the Eskimo village of Wainwright, located at $70^{\circ} 40^{\prime} \mathrm{N}$., $159^{\circ} 59^{\prime} \mathrm{W}$., on the north coast of Alaska. These demographic data are presented with a biological bias. Accordingly, I am reporting the data pertaining to recruitment (birth and immigration), death, and dispersion (emigration) that one normally obtains on any population of biological organisms that reproduces sexually, in addition to the particularly social factors which affect the reproduction of human populations.

This community is at present being studied by a multidisciplinary team of scientists under the auspices of the U. S. International Biological Program (IBP). The aim of this five-year program is to cast light upon the biological and behavioural processes responsible for the successful adaptation and the slow population growth of approximately 70,000 Eskimos in the arctic-subarctic environment (Milan 1968).

During July and August of 1968, a 19-man scientific team was in Wainwright and examined 269 of the 333 Eskimos carried on the current village census rolls. This examination included: the collection of genealogies and family histories; facial photographs, anthropometric measurements and anthroposcopic observations; a medical examination including chest, head, wrist and ankle X-rays; a complete dental examination; the collection of blood samples; the measurement of physical fitness; the determination of bone mineral content; and studies of biological rhythms. The rationale and protocol for these examinations are described in an IBP/HA Conference report (Milan 1967). The complete results of these investigations will be published by the responsible scientists as they become available.

\section{THE BREEDING ISOLATE}

Wainwright had no reason for existence as a community before 1904 . The construction of the first school house with available services during the summer of that year apparently caused the resettlement at that particular location of the remnants of the original coastal and inland Eskimo people then living in the general area of northwest Alaska. As recently as 1910, according to Wesley Ekak, a 71-year-old villager, when Van Valin (1945) was the school teacher, the Wainwrighters were still seasonal migrants. They went up the Kuk River in the fall to camp sites like Kangitc, Uyagaaruk, Anaktuuk, for fishing and caribou hunting until Christmas when they returned to Wainwright.

In 1892 Lieutenant Ray (Ray 1885) counted only 410 people in 72 family groups living on the arctic coast between Wainwright Inlet at the mouth of the Kuk River and Point Barrow, 90 air miles $(145 \mathrm{~km}$.) to the east. This total included the Eskimos living in the 2 settlements at Point Barrow. The settled coastal village of Point Hope reported 276 people in 1880 (Petroff 1884) and 295 people in 1890 (Porter 1893). Alva Nashoalook, now 70 years old and living in Wainwright, stated that there were about 45 people living at Kilimantavik, a coastal village 14 miles $(22.5 \mathrm{~km}$.) southwest of Wainwright in 1900 , the only settlement between Wainwright and Point Hope. At the turn of the century, then, 
there were slightly more than 750 persons living in coastal settlements from Point Hope to Point Barrow.

Gubser (1965) guessed that only about 1,000 inland Eskimos were living in the northern Brooks Range in the 1880's. He based this estimate on archaeological, ethnographic and historical evidence, as well as on a common-sense understanding of the ecological restrictions on the upper limits of population size for hunters living in harsh environments; this understanding was gained through an actual hunting apprenticeship with an inland Eskimo band. The total population of northwest Alaska can be estimated at less than 2,000 in 1900. Diamond Jenness (1928) has opined that the original coastal populations at Point Barrow and at the mouth of the MacKenzie River had earlier died of disease introduced at the end of the nineteenth century by commercial whalers (see Van Stone 1958) and that the majority of the Eskimos by 1913 to 1916 when he travelled along the north coast were immigrants, or their descendants, from inland areas and elsewhere. The important point here is to recognize that the Wainwright population of today is composed of descendants of Eskimos from the entire region of northwest Alaska. Their ancestors were predominantly members of interior hunting bands, especially the Utaqaamiut, but included ancestors from as far distant as the Kobuk and Noatak Rivers south of the Brooks Range, as well as people from the coastal settlements from Point Hope to Point Barrow.

About 1900, northwest Alaska was populated by people in a small number of local inland bands and people in coastal settlements of varying size, and these were part of a larger breeding and linguistic community. The local groups identified by the suffix miut attached to a geographic range as in the maps of Gubser (1965) and Spencer (1959) were not closed social systems by any means but had well-established reciprocal visiting, trading, and marriage alliances. Giddings (1961) refers to marriage alliances between persons from the Kobuk River and so-called "Arctic People" (who were Eskimos) to the north, and to families that formerly lived north of the Brooks Range and are now settled on the Kobuk River.

From discussions with older Eskimos at Wainwright, I am inclined to agree with Helge Larsen (1958) who described peoples of northwest Alaska as having had an inland-coastal cultural pattern of life. They were, as recently described by Taylor (1968), opportunistic, struggling under the physiological constraints which affect all of us and which required the "farming" of both the tundra and coastal-marine environments in order to survive. The particular environment being exploited depended upon circumstances over which they had no control. For the most part, these environments served as the Eskimo storehouse (Lee and Devore 1968) and, as can be shown by reference to historical records, an empty storehouse caused rapid and great population displacements.

\section{THE PRESENT POPULATION}

The population of this village, Wainwright, numbered 308 persons physically present in July of 1968, not including the BIA school teacher and family (5), or the Presbyterian minister and family (2). The population profile as to age and 


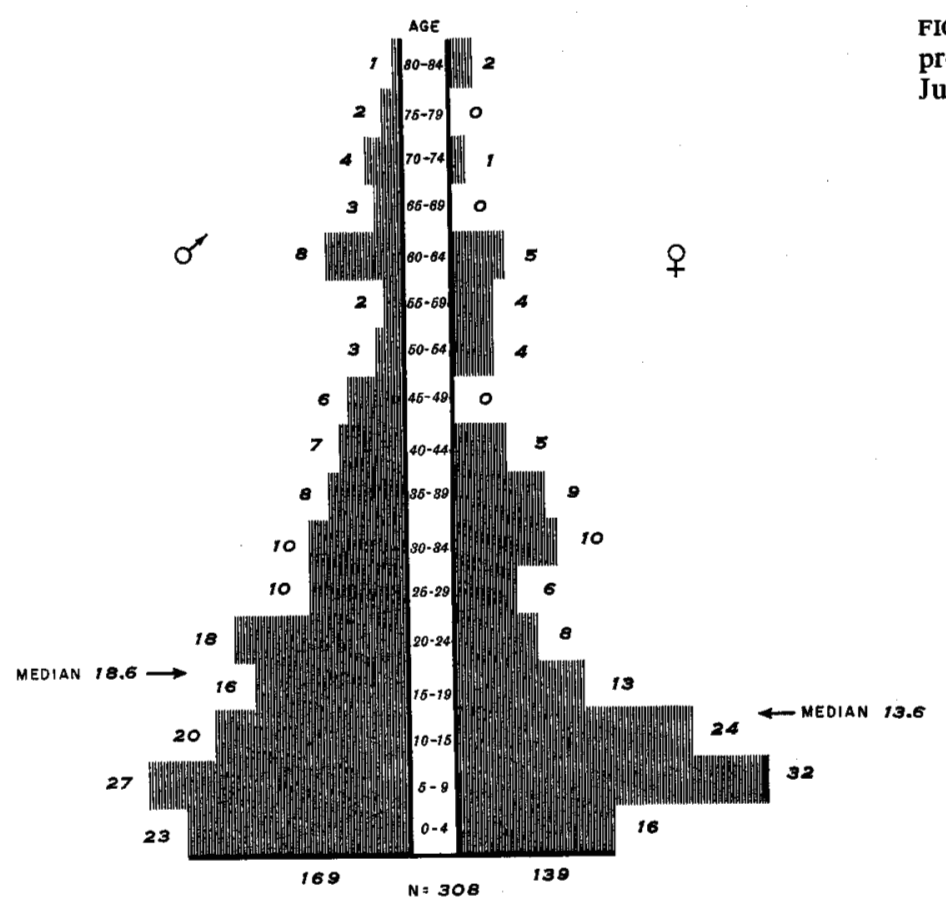

FIG. 1. Population profile for Wainwright, July 1968.

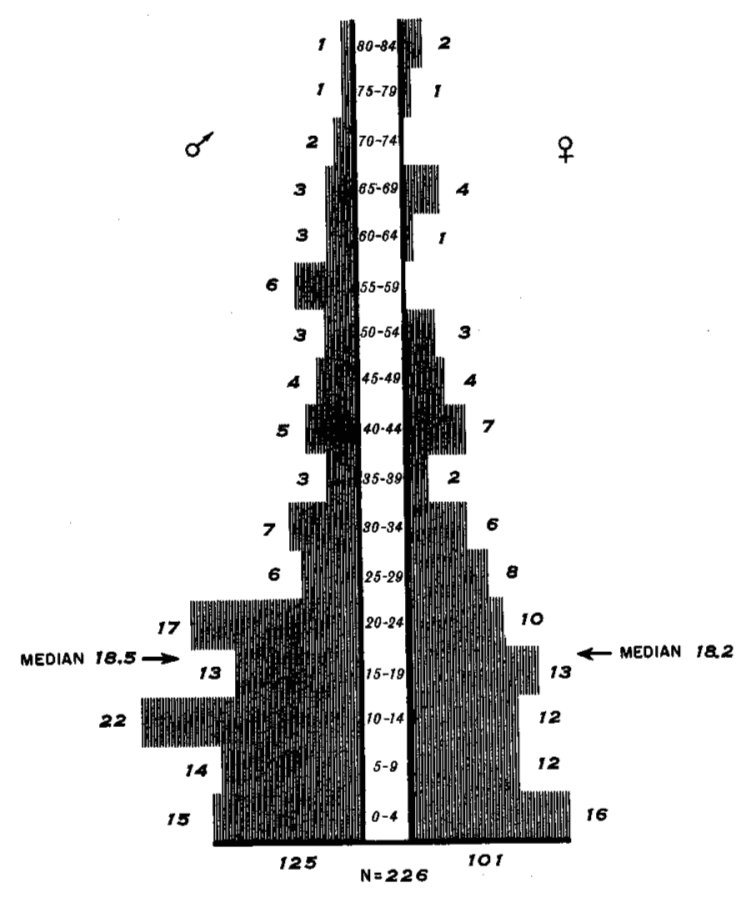

FIG. 2. Population profile for Wainwright, June 1955. 
sex is shown graphically in Fig. 1. By way of contrast, the population profile for the summer of 1955 is shown in Fig. 2 (Milan 1964); and the division of these populations into prereproductive, reproductive and postreproductive persons is shown in Fig. 3. During the 13-year interval between 1955 and 1968, 14 old persons had died, 2 complete families had moved out to Point Barrow (present population about 2,300) and 1 to Point Lay; and 3 complete families had moved into Wainwright from the Meade River, Point Lay, and Fairbanks.

TABLE 1. Generational summary 1968

\begin{tabular}{|c|c|c|}
\hline \multicolumn{3}{|l|}{ Date of Birth } \\
\hline $1887-1905$ & Great Grandparental & 3 (including one widow) \\
\hline $1890-1910$ & Grandparental & $\begin{array}{l}30 \text { (including } 4 \text { widows, } \\
4 \text { widowers and } 2 \text { divorced } \\
\text { persons) }\end{array}$ \\
\hline $1910-1920$ & Parentals & $\begin{array}{l}65 \text { (including } 1 \text { widower, } \\
1 \text { divorced, } 1 \text { unmarried } \\
\text { mother) }\end{array}$ \\
\hline 1930 & Children* & $\begin{array}{l}210 \text { (in } 61 \text { sibships; } \\
6 \text { children adopted) }\end{array}$ \\
\hline
\end{tabular}

*Includes one childless marriage and therefore not qualifying the couple, born in 1900 , for membership in the parental generation.

The generational summary for the 1968 population is presented in Table 1. The great-grandparental generation came from the Wainwright area, although one is a hybrid being one-half non-Eskimo. The grandparental generation were born at Point Hope (6), Point Barrow (1), and the rest (23) are descendents of Utaqaamiut and Kungmiut who were either born in inland camps or at summer camps or semipermanent settlements on the coast at places like Icy Cape, Point Lay, or Point Franklin.

As an illustration of cross-band marriage alliances and the nomadism of some of the Eskimos at this time, we can consider the life history of one of the members of this grandparental generation. He was born just before 1900 in a camp on the Colville River, but his mother came from the Kobuk River drainage, and his biological father, after a wandering life, finally settled with the nunamiut of

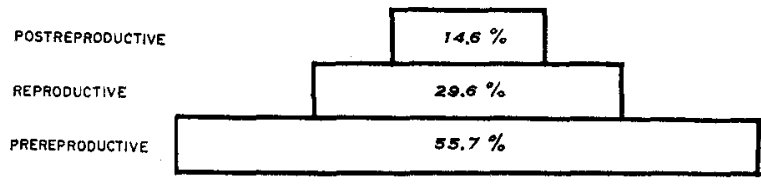

WAINWRIGHT POPULATION 1968

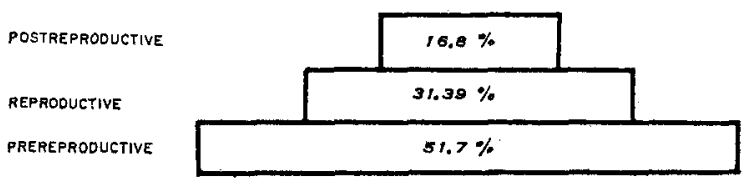

WAINWRIGHT POPULATION 1955
FIG. 3. Division of the 1955

and 1968 populations into prereproductive, reproductive and postreproductive categories. 
Anaktuvuk Pass. His mother remarried a man from the Noatak River, but my informant had spent his boyhood at Herschell Island and as far afield as Aklavik. He travelled from Herschell Island to Point Barrow slightly after 1900 in the same umiak as a now-dead and famous nunamiut caribou hunter of Anaktuvuk Pass. He eventually settled at Icy Cape and was married aboard the cutter Bear to a woman whose mother had been south as far as Nome by whaling ship and whose grandmother had descendants living in Point Hope. This person has half brothers and sisters at Kotzebue and Point Barrow.

The Wainwright population is not all 100 per cent Eskimo insofar as race is concerned. About 67 persons are hybrids; 3 of these are one-half non-Eskimo, 19 are one-fourth Eskimo and 45 are one-eighth Eskimo. Hybridization was through admixture with whalers slightly before 1900 . These whalers who contributed genes to Wainwright were "Old Americans," Portuguese, and others, even including a Kanaka from the South Seas as shown by the positive Diego reaction in the blood of one Wainwrighter in the analysis carried out by Corcoran et al. (1959), and confirmed by personal interviews.

\section{REPRODUCTIVE HISTORIES}

Birth and death statistics for northern Alaska under-report vital events of interest to biologists and demographers. For this demographic study I utilized genealogical information collected sporadically over a number of years, and reproductive histories obtained in January 1968 with the assistance of Mrs. Emily Ungadruk, the village health aide (see Bystrova 1965). These reproductive histories were elicited directly from 47 now-living Wainwright women of reproductive age and indirectly from the relatives of 11 now-dead married women. Names of all children were obtained so that they could be referred to the genealogies and traced over time. Most of the births were in the village and were attended by the local midwives.

In the now-living group, the oldest woman was 82 and the youngest 21 . Of this group of 47 women, 17 were already postmenopausal (mean age at menopause $44.5 \pm 4.3$ years), 1 was infertile, and 3 were no longer able to have children because of surgery undertaken at a hospital for various and unknown reasons.

Fourteen women of this sample were using modern methods of fertility control under the direct supervision of a physician. Twelve women had intrauterine devices installed (cf. Tietze 1965) and 2 were taking oral contraceptives (cf. Parkes 1965).

The mean age at menarche for this now-living sample was reported as $13.78 \pm$ 0.786 years by 46 women.

\section{Number of Pregnancies}

Forty-six of these now-living mothers reported 364 separate pregnancies or 7.9 pregnancies per woman. The 17 postmenopausal women reported 159 pregnancies or an average of $9.9 \pm 4.08$ pregnancies. This average figure includes one completely infertile woman, now postmenopausal. 


\section{Twinning Rate}

There were 9 sets of twins brought to full term. Six sets were of the same sex and 3 sets were differently sexed. This means that out of 364 conceptions, 373 fetuses were produced. The incidence of twinning was 2.73 per cent of all live births.

\section{Abortion Rate}

The spontaneous abortion rate was 10.16 per cent of all pregnancies with 37 aborted fetuses reported by 19 women. For this study, an aborted fetus was defined as "fetal age less than 6.5 months" after Warburton and Fraser (1964).

\section{Number of Live Births}

This sample of 46 Wainwright women reported 329 live births. The 44 conceptions that did not survive uterine life to be born live included the 37 abortions and 7 either premature or still-born children.

\section{Sex Ratio}

The proportion of the sexes at birth for the 329 live births was 170 males to 157 females. The sex of 2 live births was unreported. The sex ratio, then, was 108.2 males born for every 100 females born alive. It was impossible to obtain the sex of still-births or aborted fetuses with any degree of completeness, and that sex ratio cannot be calculated.

\section{Mortality Data}

Of the 329 infants born alive 251 are still living. Their distribution as to sex,

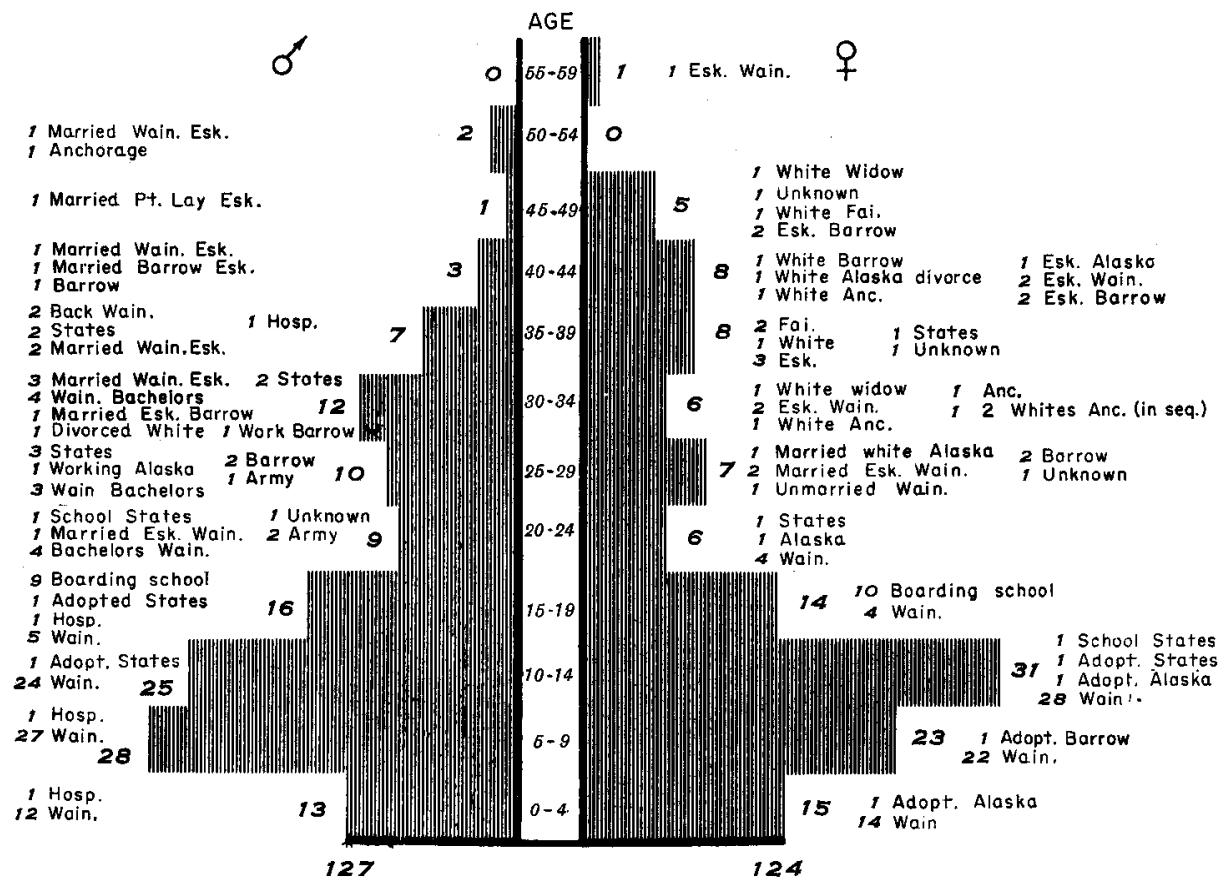

FIG. 4. Age profile for now-living children born to 45 now-living Wainwright mothers. 
age and fate are illustrated in Fig. 4. Information about the age, sex and the mother's reported cause of death for $\mathbf{7 2}$ of the $\mathbf{7 8}$ that have died since birth is shown in Fig. 5.

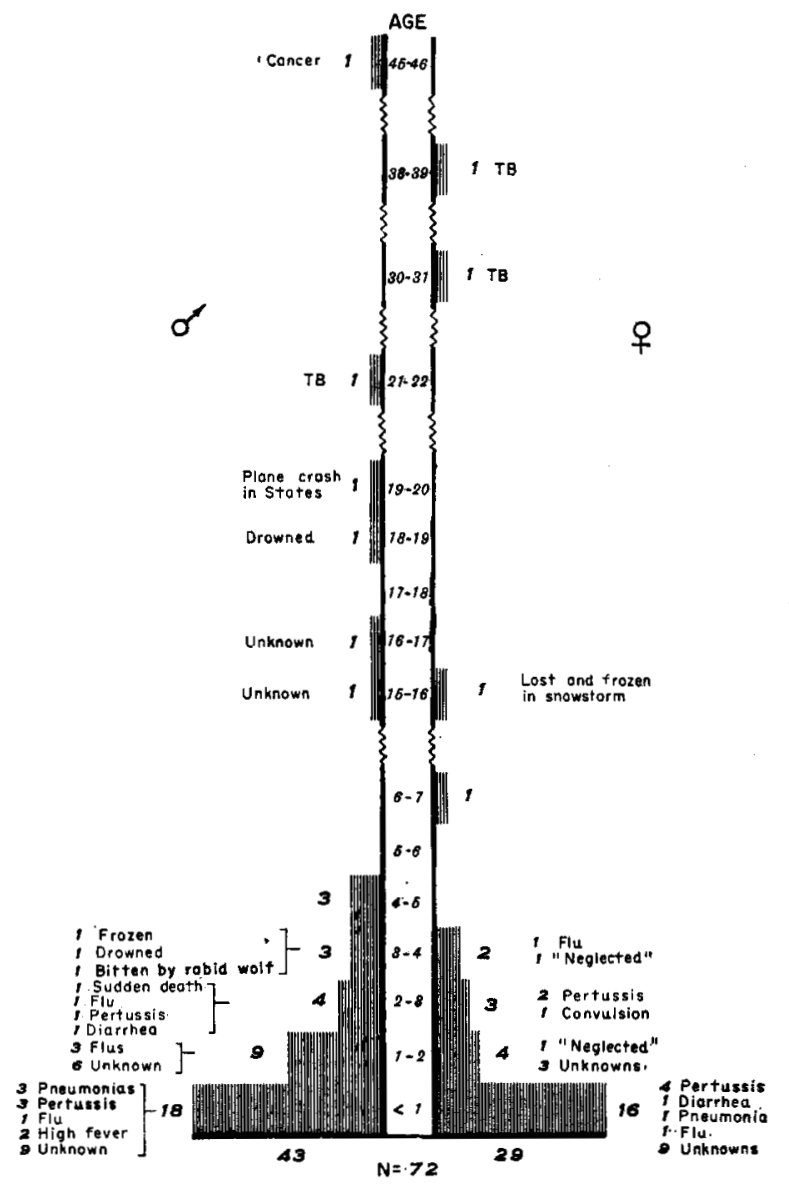

FIG. 5. Sex, age and cause of death of 72 children born live to 42 Wainwright women in a total sample of 329 live births.

\section{Deformed or Injured at Birth}

Deformed or retarded children numbered 11 or 3.02 per cent of the 364 pregnancies. This included 5 who were "mentally retarded," several of whom have been institutionalized, several have died, and one remains in the village. Three had cleft palates, and the remainder were born with gross abnormalities and did not survive long after birth.

\section{Items of Sociological Interest}

Approximately 14 children were born to 7 women in this sample previous to marriage. One woman married the father of her two children, 6 did not, and one mother of two children resuained unmarried; she was pregnant when these histories were collected. Four marriages in the parental generation were consanguineous. 


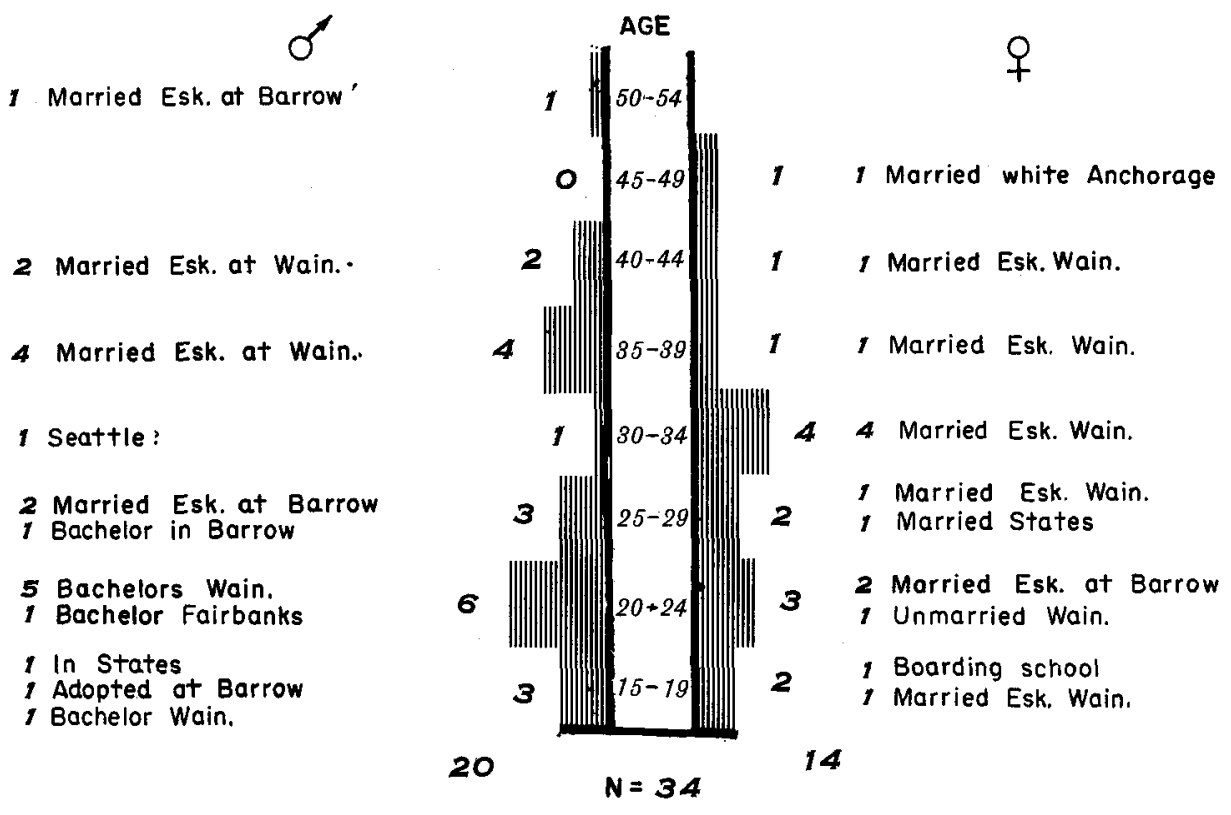

FIG. 6. Age profile for now-living children born to 11 now-dead Wainwright mothers.

\section{The Deceased Sample}

Reproductive histories were obtained from the relatives of the 11 now-dead women. One woman of this group was infertile. These women died between 1928 and 1955 of tuberculosis (3), typhoid (1), in childbirth (2), and of unknown causes (5). As a group they were characterized by a relatively young age at death. Age at death of these women and number of live births were as follows: 19 ( 2 children), 26 ( 4 children), 29 ( 7 children), 31 ( 8 children), 32 ( 7 children), 33 (14 children), 44 (12 children), 65 ( 0 children), and two women who died at an unknown age producing 3 and 7 children each.

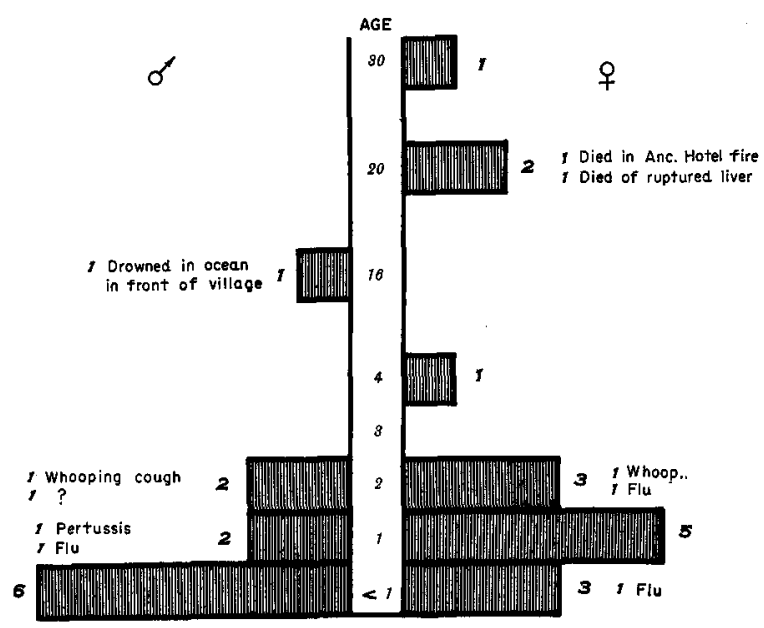

FIG. 7. Number, sex and age at death for 26 children born live to 11 now-dead Wainwright mothers. 
These 11 women produced 34 males, 30 females. This series included one set of triplets and one set of same-sexed twins.

At present 35 of the total of 65 live-born children are still living, and the information as to age, sex-distribution and provenience is presented in Fig. 6 . The sex and age distribution at death and cause of death according to the living relatives is shown in Fig. 7 .

TABLE 2. Ratio of live births to now-living progeny for 21 now-living postmenopausal Wainwright mothers.

\begin{tabular}{ccc}
\hline Rank & Number of Women & Live Born/Now Living \\
\hline 1 & 1 & $13 / 12$ \\
2 & 3 & $41 / 33$ (11 each) \\
3 & 1 & $14 / 9$ \\
4 & 1 & $9 / 8$ \\
5 & 2 & $17 / 14(7 \mathrm{each})$ \\
6 & 1 & $11 / 6$ \\
7 & 4 & $39 / 20(5 \mathrm{each})$ \\
8 & 1 & $4 / 3$ \\
9 & 5 & $29 / 10(2 \mathrm{each})$ \\
10 & 2 & $2 / 0$ \\
\hline Totals & 21 & $179 / 115$ \\
\hline
\end{tabular}

\section{Differential Reproduction}

The number of now-living progeny from the 21 now-living women who are postmenopausal (17), sterile (3), and barren (1) is shown in Table 2. The same information is presented in Table 3 for the sample of now-dead women. Table 2 shows that 4 women, or less than one-fifth of the total number of women, are responsible for 47 per cent of the living offspring. Table 3, similarly, shows that 2 women, again one-fifth of the total, are responsible for 46 per cent of the living offspring. The slight difference between the two samples is only in the ratios of live births to now-living offspring. The earlier sample had a survival rate of 56 per cent in contrast to 64 per cent for the later sample.

TABLE 3. Ratio of live births to now-living offspring for 10 mothers who died between 1928 and 1955.

\begin{tabular}{|c|c|}
\hline Number of Women & $\begin{array}{c}\text { Ratio } \\
\text { Live Born/Now Living }\end{array}$ \\
\hline 1 & $12 / 9$ \\
\hline 1 & $13 / 7$ \\
\hline 1 & $6 / 5$ \\
\hline 1 & $7 / 4$ \\
\hline 3 & $17 / 9$ (3 each) \\
\hline 1 & $3 / 1$ \\
\hline 2 & $4 / 0$ \\
\hline Totals 10 & $62 / 35$ \\
\hline
\end{tabular}




\section{Population Trends}

DISCUSSION

Between 1955 and 1968 the Wainwright population increased by 82 persons. As shown in Fig. 3, the increase was in the lower age brackets i.e., in the number of children. This can be seen from the median age calculated for these two population pyramids. The median age for 1955 was 18.5 for males and 18.2 for females. In 1968 the median age for males was 18.6 but only 13.6 for females. The lower median age for females is a function of the comparatively higher mortality rate for males as shown in Fig. 5. This is a young population and in that respect is comparable to the 1960 Alaskan Eskimo population which had a median age of 16.1 for males and 15.7 for females. The Alaskan White population, also youthful in structure, has a median age of 24.5 for males and 23.5 for females. By way of contrast, the U.S. White population had a median age of 29.5 which had fallen from the figure of 30.3 reported in the 1950 census (U.S. Census of Population 1950; 1960).

The fact that this is a young population in Wainwright has two important social concomitants. As a result of the increased number of children, The Bureau of Indian Affairs school increased its staff from 2 to 4 in order to teach the 97 students enrolled in 1968. Secondly, an increasing proportionally large number of women and children are dependent for support upon a relatively small number of adult male producers.

The apparent result of the fertility control program is observable in the age category 0-4 in Fig. 1 where, if the normal arithmetic progression had continued, about 40 more children would have been added by 1968 . This systematic fertility control program has been in operation for about 4 years and is sponsored by the U.S. Public Health Service.

\section{Multiple Births}

The twinning rate of 27.3 per thousand for the now-living mothers is very high and is over twice as great as the twinning incidence of between 10.4 and 11.3 per thousand births reported by Guttmacher (1953) for the U.S. "White" population between the years 1928 to 1949 . It has been demonstrated that there are marked racial differences in twinning rates ranging between approximately 44.0 per thousand in Nigeria (Harrison et al. 1964) to 16.3 per thousand in east Finland (Eriksson and Fellman 1967), with a low of 6.6 per thousand reported for Japan (Guttmacher 1953). The last-mentioned author, with reference to twinning incidence data collected at 10 German University Clinics in different cities, has shown the danger of concluding that the twin incidence of all small samples are representative of the total population. Wainwright probably does not represent the Eskimo population at large, for high twin frequencies in isolated populations suggest recessive traits to some authors (Eriksson 1962), and it has always been asserted that multiple births are least common in Mongoloids. There is no apparent relationship between the mother's age and twinning as shown in Fig. 8 .

Weinberg (1902) recognized from probability considerations that one-third of twin births are monozygotic and two thirds dizygotic. The 9 sets of Wainwright 


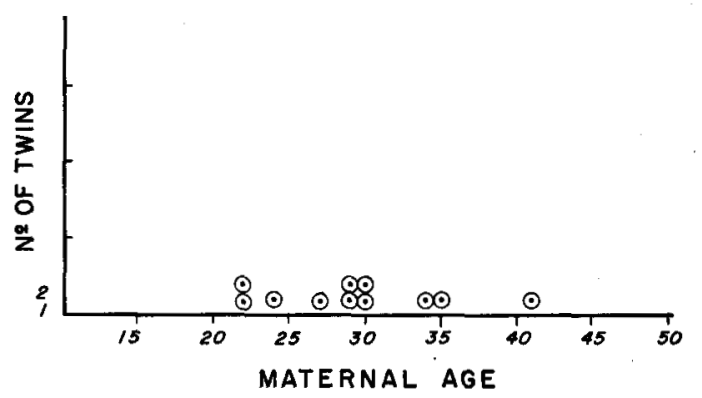

FIG. 8. Number of twins versus maternal age for both samples.

twins are 3 of different sex and 6 of the same sex. According to probability, then, these should represent 3 monozygotic and 6 dizygotic sets, since if we subtract from the total number of like-sexed the total number of unlike-sexed, the remainder should equal the total number of one-egg pairs. Of the 18 twins born, 5 same-sexed twin sets survived plus two more of opposite-sexed pairs, making a total of 12 or a survival rate of 67 per cent, which is about 20 per cent less than reported for 523 twins delivered in a Hartford, Connecticut, hospital (Klein 1964).

\section{Abortion Rates}

Warburton and Fraser (1964) defined an abortion as the termination of a recognizable uterine pregnancy at less than $61 / 2$ months of gestation, the period before which fetal viability outside the uterus is doubtful. Their data on frequency of occurrence of spontaneous abortion were derived from 558 families taken at the Montreal Children's Hospital during the years 1952 through 1962. The overall frequency reported was about 15 per cent of all pregnancies. The Wainwright data show a rate of slightly over 10 per cent which may reflect a real difference or merely be under-reporting on the part of the mothers. As shown in Fig. 9, the frequency of spontaneous abortions rises with maternal age.

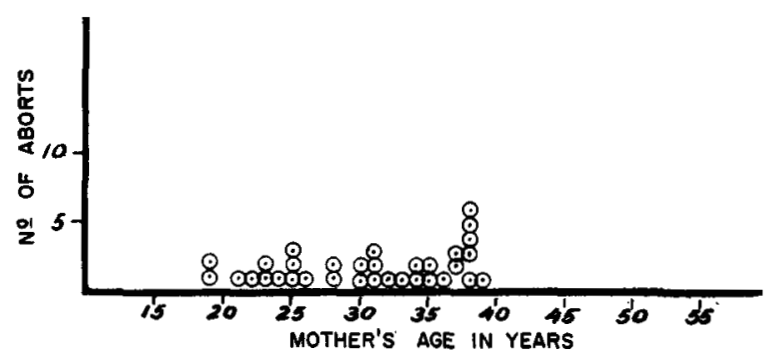

FIG. 9. Frequency of spontaneous abortions versus mother's age in years for 20 women.

\section{Birth Rates}

The 1964 birth rate for all Alaska natives according to registered live births per 1,000 population is reported as 45.7 (Indian Health Highlights 1966). Maynard (1967) reported a crude birth rate of 53 per thousand in the Bethel area. The 1961 birth rate for all of Greenland was reported at 50.2 per thousand (Bech 1963a). The Wainwright data show a similarly high birth rate; but because of the method of collection, the only directly comparable figures for Eskimos are those collected by Taylor (1966) who obtained reproductive histories from 
17 of 24 women who had experienced one or more pregnancies in the village of Karluk on Kodiak Island. He reported a mean value of 4.97 children for all women of all ages and 6.40 children for producing women. It can be seen, then, that the values for the Wainwright women with 7.1 live births for all women and 10.5 live births for 16 postmenopausal producers are much higher in comparison. Hrdlicka (1936a) reported a total of 168 children born to 27 postmenopausal women among Kuskokwim River Eskimos in 1930, or an average of 6.2 live born children per mother.

In Wainwright only two women of the total of 58 surveyed were infertile.

With regard to chance of pregnancy, the number of years at risk versus number of pregnancies for 15 postmenopausal Wainwright women is shown in Fig. 10.

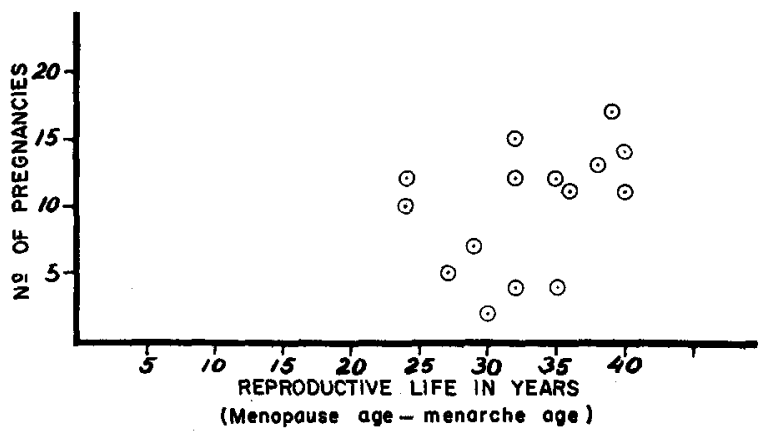

FIG. 10. Number of pregnancies versus years at risk for 15 post-menopausal women.

The Wainwright sex ratio at birth of 108.1 males per 100 females is higher than the world sample of $102 / 100$. The sex ratio at birth in Korea reveals the highest ratio among the world's populations being 114.99 males per 100 females (Kang and Cho 1959). In contrast, Weyer (1932) commented on the preponderance of females in the eastern Arctic. Greenland for 1961 reported 94.2 males per 100 females (Bech 1963a), and this inverse relationship was confirmed with 85.9 males for 100 females in a sample of 756 live births in the Godthaab district of Greenland between 1957 and 1964 by Harvald and Hels (1968). Osborn (personal communication, 1969) suggested that these differences are more probably due to a larger number of stillbirths and abortions than are reported by vital statistics, rather than a case of meiotic drive, and illustrate the lower viability of male zygotes in general.

\section{Mortality}

The death rates for the two Wainwright samples may be considered separately with respect to death before the age of five years which, as can be seen in Fig. 11, is apparently an extremely critical age for survival. The earlier sample showed that of the 65 born alive, only 43 or 66.1 per cent survived to age 5 . The other sample of 329 born live showed that 81.15 per cent survived to age 5 . The survival of the children resembles that of the parents. The combined samples yield a mean survival percentage of 79.4 per cent. Taylor (1966) reported 71.4 per cent for Koniag Eskimos at Karluk. The U.S. rate was 97.3 per cent for 1959 and for Greenland 87.7 per cent between 1952 and 1959 according to the United Nations Demographic Yearbook (1961). 


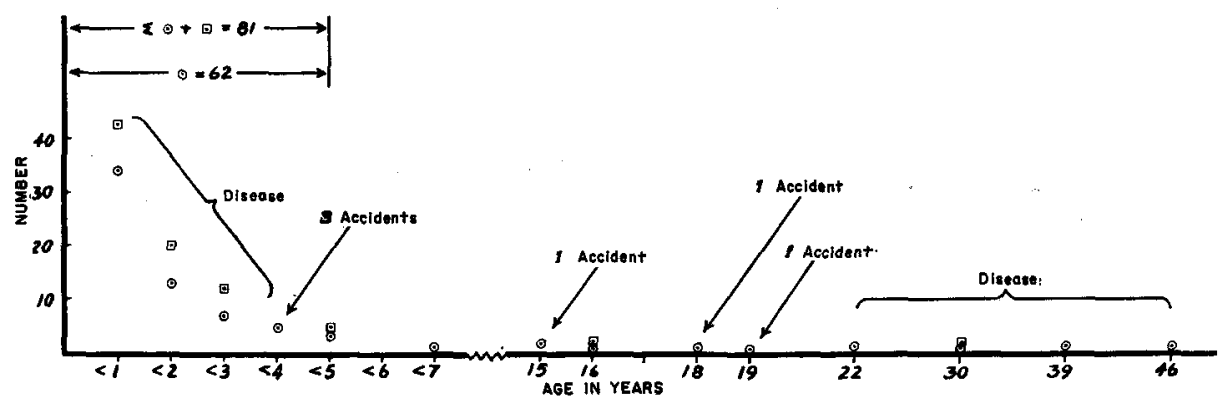

FIG. 11. Graph showing age at death for 72 children born live (circle) to 42 now-living Wainwright women in a sample of 329 live births plus 26 children born live (square) to 11 now-dead women in a sample of 65 births.

Maynard (1967) has provided comparable statistics for the Bethel area and stated that for the years $1956-58$ mortality was about 140 deaths per 1,000 live births and 84 per 1,000 live births for the Kotzebue-Barrow area. This was about five times the rate for the U.S. as a whole.

In addition to purely "biological" causes of death, it should be emphasized that Fig. 5 lists several "social" or "environmental" causes for the death of children, especially after they are 3 to 4 years old and they are ambulatory relatively unsupervised in a hazardous region. Surprisingly, accidental death for male hunters in Wainwright is almost nonexistent despite the evidence of Haldeman's (1951) study which showed violent accidental death to be a major public health problem in Alaska.

The Wainwright data for the sample of now-living mothers illustrates differential mortality. This is because of the lesser viability of males in general as reported, for example, by Gordh (1964), and there are nearly twice as many male as female deaths below age 5 in Wainwright.

\section{Menarche and Birth}

The Wainwright women reported menarche at $13.78 \pm 0.786$. This figure is lower than the mean reported by Levine (1953) of $14.42 \pm 1.20$ for 120 women at Point Barrow and may be an evidence of a secular trend observable around the world towards lower age at first menstruation reported by a number of authors. According to Hiernaux (1968), the age at menarche for all mankind shows a wide range of variation between 12.3 and 18.8 years, and the possible

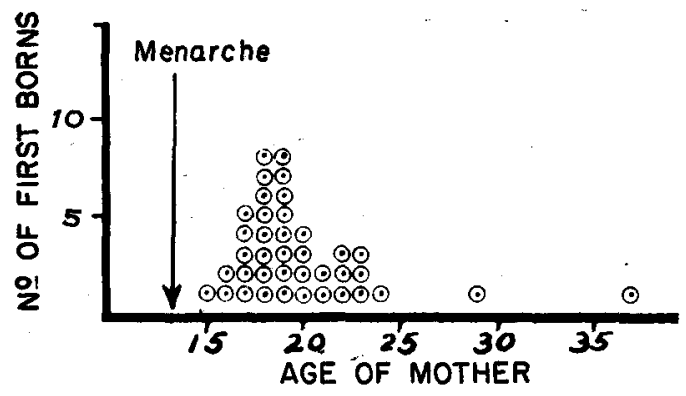

FIG. 12. Number of first borns versus age of mother for 39 mothers. 
determinants are nutrition, disease, rurality, altitude, and a genetic component. Interestingly, Hrdlicka (1936b) reported the menarche age of 16 women at Bethel at 13.3 years in 1930 .

As shown in Fig. 12, the most frequently occurring mother's age for the first born child is 18 in a sample of 39 . Given the lack of inhibition of sexual intercourse of Eskimo adolescents reported elsewhere (Stevenson 1968, p. 9), which I can neither confirm nor deny for Wainwright, and the absence of contraceptive devices not requiring medical intervention (in contrast to Greenland where the condom can be purchased in all K.G.H. stores even in the smallest settlements [Bech 1963b, p. 53]) these data indicate either a post-puberty anovulatory period (Montague 1946) of several years for Eskimo girls, coitus interruptus, or abstention.

\section{Emigration}

Fig. 4 shows the amount of out-migration in the sample of 251 offspring produced by the now-living Wainwright women. One hundred and twenty-four of these progeny are females and 41 are over age 20 . Of this number 10 (24 per cent) married white men at Point Barrow or elsewhere in Alaska, 8 married Eskimos from outside the village, and only 5 remained in Wainwright to marry Wainwright males. Only 5 potentially marriageable bachelor girls between 20 and 29 remain in Wainwright.

The Wainwright males, by contrast, have generally remained in the village or returned to the village after an absence. Of the 127 male progeny in the sample of 251, 44 are over age 20. Eight men married Eskimo women born in Wainwright, and 3 men married women from Point Lay or Point Barrow and brought them to Wainwright, while 13 still remain as bachelors in Wainwright. The others are in the Army (3), working elsewhere in Alaska (4), or in other States (6), or their whereabouts are unknown (3).

Apparently, Wainwright women have higher physical and social mobility than men. The four years spent in boarding high schools outside the village adequately prepares them for life elsewhere. Association with whites later in life effectively counteracts childhood indoctrination universally practised in Wainwright families where white Europeans are labelled as "bogey-men equivalents" to encourage children to conform to family behaviour norms.

\section{CONCLUSIONS}

In this paper I have discussed the demography of a contemporary Alaskan Eskimo village by using information from reproductive histories obtained from all women of reproductive age. From these data it is concluded that one of the biological reasons for the adaptive success of these Eskimos over the last seventy years has been the extremely high fecundity of the population. There is only slight evidence in the histories for intentional birth spacing until recently. A high infant mortality, for any reason, served as an effective regulator of population size in the past. Mortality rates have decreased in response to improved health care and hygienic measures. This "death control" has resulted in a population increase of 
about 3 per cent over the last 13 years. The increase is similar to that in the developing countries of Africa, Asia and Latin America with an average doubling time of only 25 years. And, indeed, the population of the northwest coast of Alaska has increased from about 2,000 persons at the turn of the century to approximately 3,000 seventy years later.

Reactions opposing growth have been triggered, for at present 29 per cent of the women are practising medically-supervised "birth control" and out-migration of marriageable girls is increasing. It has been estimated that the percentage of women of child-bearing age participating in the Division of Indian Health's family planning program in Alaska increased from about 3 per cent in 1965 to 63 per cent in 1967 (Federal Field Committee 1968).

These modern methods of "birth control" being practised today will soon make birth rate, not mere differential survival, the major determinant of the genetic content of each succeeding generation.

\section{ACKNOWLEDGEMENT}

This research was supported by the U.S. Air Force Office of Scientific Research under grant 68-1593C.

\section{REFERENCES}

BECH, v. 1963a. Sundhedstilstanden i Grønland: Landslagens årsberetning. 1961. Godthåb: Sydgrønlands Bogtrykkeri, 83 pp.

1963b. Familieplanlægning. Inôkatigît agdlisitsiumik . . . Hverdagen under lup. Godthåb: Oplysningsrådet for Grønland; Sydgrønlands Bogtrykkeri, 153 pp.

BYstrova, v. A. 1965 . The anemestic method of studying demographic processes. Proceedings of the World Population Conference. United Nations Publication, 66: XIII, 7. New York, pp. 131-36.

CORCORAN, P., F. H. ALLEN JR., A. C. ALLISON and B. S. BLUMBERG. 1959. Blood group of Alaskan Eskimos and Indians. American Journal of Physical Anthropology, 17: 187-93.

ERIKSSON, A. W. 1962. Variations in the human twinning rate. Acta Genetica et Statistica Medica, 12: 242-50.

ERIKSSON, A. W. and J. FellmaN. 1967. Twinning in relation to the marital status of the mother. Acta Genetica et Statistica Medica, 17: 385-98.

FEDERAL FIELD COMMITTEE FOR DEVELOPMENT PLANNING IN ALASKA. 1968. Alaska natives and the land. Washington: U.S. Government Printing Office. 565 pp.

GIDDINGS, J. L. 1961. Kobuk River people. University of Alaska Studies of Northern Peoples, Number $1.166 \mathrm{pp}$.

GORDH, T. 1964. The influence of sex on anesthetic morbidity and mortality. Anesthesiology, 25 (4): 466-69.

GUBSER, N. J. 1965. The Nunamiut Eskimos: Hunters of caribou. New Haven: Yale University Press. 384 pp.

GUTTMACHER, A. F. 1953. The incidence of multiple births in man and some other unipara. Obstetrics and Gynecology, 2: 22-35.

HALDEMAN, J. E. 1951. Violent and accidental deaths as a health problem in Alaska. Science in Alaska. Proceedings of the Second Alaska Science Conference, Alaska Division. American Association for the Advancement of Science. pp. 103-18. 
HARRISON, G. A., J. S. WEINER, J. M. TANNER and N. A. BARNICOT. 1964. Human biology: An introduction to human evolution, variation. Oxford: Clarendon Press. $536 \mathrm{pp}$.

HARVALD, B. and J. HELS. 1968 . The incidence of congenital malformations in Greenlandic Eskimos. Paper presented at Nordisk Human $ø$ kologisk Symposium: Copenhagen.

HIERNAUX, J. 1968. Ethnic differences in growth and development. Eugenics Quarterly, 15 (1): $12-21$.

HRDLICKA, A. 1936a. Fecundity of Eskimo women. American Journal of Physical Anthropology, 22: 91-95.

1936b. Puberty in Eskimo girls. Proceedings of U.S. National Academy of Science, 22: 355-57.

INDian hEalth HIGHLights. 1966. U.S. Department of Health, Education and Welfare. Public Health Service, Bureau of Medical Services, Division of Indian Health, Washington, D.C. $65 \mathrm{pp}$.

JENNESS, D. 1928. Comparative vocabulary of the western Eskimo dialects. Report of the Canadian Arctic Expedition, 1913-18, Vol. 15. Ottawa: King's Printer. 134 pp.

KANG, Y. S. and w. K. CHO. 1959. The sex ratio at birth of the Korean population. Eugenics Quarterly, 6 (3): 187-94.

KLEIN, J. 1964. Perinatal mortality in twin pregnancy. Obstetrics and Gynecology, 23: $738-44$.

LARSEN, H. 1958. The material culture of the Nunamiut in relation to other forms of Eskimo culture in northern Alaska. Proceedings of the Thirty Second International Congress of Americanists, Copenhagen. pp. 574-82.

LEE, R. B. and I. DEVORE. 1968. Man the Hunter. Chicago University Press. 415 pp.

LEVINE, V. E. 1953. Studies in physiological anthropology, II. The age of onset of menstruation of the Alaskan Eskimo. (Abstract). American Journal of Physical Anthropology, $11: 252$.

MAYNARD, J. 1967. Eskimo infant deaths twice Indians. Medical Tribune. February. pp. 25-26.

MILAN, F. A. 1964. The acculturation of the contemporary Eskimo of Wainwright, Alaska. Anthropological Papers of the University of Alaska. 11 (2): 1-95.

1967. (Editor) Report of the Working Party: Conference for the IBP/HA Study of Circumpolar Populations, University of Wisconsin (Mimeo). $110 \mathrm{pp.}$

1968. The international study of Eskimos. Arctic, 21: 123-26.

MONTAGUE, A. M. F. 1946. Adolescent sterility. Springfield: Charles Thomas. 148 pp.

PARKES, A. S. 1965. Biology of human fertility and its control. In: C. Sheps and J. C. Ridley, eds. Public Health and Population Change. University of Pittsburgh Press. pp. 417-31.

PETROFF, I. 1884. Report on the population, industries, and resources of Alaska. In: Tenth Census of the U.S. Washington.

PORTER, R. P. 1893. Report on population and resources of Alaska. Eleventh Census of the U.S.: 1890. Washington.

RAY, P. H. 1885. Ethnographic sketches of the natives of Pt. Barrow. Report of the International Polar Expedition to Point Barrow, Alaska. Washington: Government Printing Office. pp. 35-89.

SPENCER, R. F. 1959. The North Alaskan Eskimo: A Study in Ecology and Society. Bureau of American Ethnology Bulletin 171.490 pp.

STEVENSON, D. S. 1968. Problems of Eskimo relocation for industrial employment. Canada Department of Indian Affairs and Northern Development, Northern Science Research Group, 68-1. 
TAYLOR, K. I. 1966. A demographic study of Karluk, Kodiak Island, Alaska 1962-1964. Arctic Anthropology, 3 (2): 211-40.

TAYLOR, W. E. 1968. An archaeological overview of Eskimo economy. In: J. F. Valentine, ed. Eskimo of the Canadian Arctic. Toronto: McClelland \& Stewart. pp. 3-17.

TIETZE, c. 1965 . History and statistical evaluation of intrauterine contraceptive devices. In: C. Sheps and J. C. Ridley, eds. Public Health and Population Change. University of Pittsburgh Press. pp. 432-49.

UNITED NATIONS DEMOGRAPHIC YEARBOOK. 1961. Statistical Office of the United Nations. Department of Economic and Social Affairs. United Nations, N.Y.

U.S. CENSUS OF POPULATION: 1950 and 1960.

Van Stone, J. 1958. Commercial whaling in the Arctic Ocean. Pacific Northwest Quarterly. 49 (1): $1-10$.

van valin, w. B. 1945. Eskimoland speaks. London: Museum Press. 202 pp.

WARBURTON, D. and F. FRASER. 1964. Spontaneous abortion risks in man: Data from reproductive histories collected in a medical genetics unit. American Journal of Human Genetics, 16: $1-25$.

WEINBERg, w. 1902. Beiträge zur Physiologie und Pathologie der Mehrlingsgeburten beim Menschen. Archiv der Gesellschaft für Physiologie, 88: 346-430.

WEYER, E. M. 1932. The Eskimos: their environment and folkways. New Haven: Yale University Press. 491 pp. 